\title{
DEPOLITICIZING THE FIRM: REVISITING EMPLOYABILITY AS A STRATEGY AND A NARRATIVE FOR HIGH-SKILLED AND SKILLED WORKERS IN AN EASTERN EUROPEAN CITY
}

\author{
NORBERT PETROVICI ${ }^{1}$, NEDA DENEVA-FAJE ${ }^{2}$
}

\begin{abstract}
Our main aim is to unpack the notion of employability as a narrative and as a strategy by contextualising it in an Eastern European setting and by scrutinizing how it is defined and experienced by two different categories of employees: high-skilled and skilled workers. We look at the case of Cluj, a mid-size Romanian town fast developing into an IT hub and a centre of reindustrialization. Drawing on qualitative interviews with employees in the IT and HR sectors, and in medium-sized factories, we argue that personal development and gaining expertise are a successful employability strategy for the highskilled, but make the skilled workers more vulnerable and at risk of becoming redundant. We argue that the employability discourse draws new lines of divisions between employees. By shifting the lens away from the organization and towards the individual worker's responsibility, the employability discourse depoliticizes the relationship between the employee and the employer.
\end{abstract}

Key words: employability, narratives of work, personal development, class divisions

\section{Introduction $^{3}$}

The employability discourse is a dominant trope that is mobilized at various levels of the labour market from policy, through employers and managers, to the workers themselves. It promises a new type of job security which is tied to being employable in various companies and positions based on the skills

1 Department of Sociology, Faculty of Sociology and Social Work, Babeș-Bolyai University, St. Avram Iancu, no. 68, 4th level, Interdisciplinary Centre for Data Science, norbert.petrovici@ubbcluj.ro.

2 Department of Sociology, Faculty of Sociology and Social Work, Babes-Bolyai University, St. Avram Iancu, no. 68, 4th level, Interdisciplinary Centre for Data Science, neda.denevafaje@ubbcluj.ro.

3 The first stage of the research was part of a research grant funded by ERSTE foundation for Social Research. The second stage was conducted as part of the project ROTECH PN-III-P1-1.1-TE-20161691, in the framework of the UEFISCIDI funding scheme. 
and expertise that workers build. It is tightly connected to the concept of building one's own career through a series of successive positions. In this paper we aim to unpack the notion of employability by contextualizing it in an Eastern European setting and by scrutinizing how it is defined and experienced by different categories of employees. We have chosen to look specifically at highskilled workers in the field of IT and HR and at skilled workers in the manufacturing industry. We aim to trace the differences in the employability discourse in these two categories of workers and the consequences for their trajectories and relations with the organization.

We look at the case of Cluj, a mid-size, fast developing Romanian town which has turned into one of the major IT hubs of the county, while also witnessing a wave of reindustrialization in its metropolitan area. We chose to explore how employability is perceived and constructed from the point of view of the employee in two sectors where there is a growing demand for labour - the IT industry and the small production companies. The empirical analysis is based on a series of qualitative interviews with employees conducted in two periods - in 2013 and in 2018-2019. We have focused on various positions in the IT sector - developers and coders, business analysts, and HR recruiters that we call the 'high-skilled' workers. The other category are technicians of machines in small industrial firms that we call the 'skilled workers'.

We focus more specifically on the relationship between the employee and the firm as a site where employability is mobilized in a series of modes. We argue that the firm has increasingly lost its role as providing a stable working position and the place to develop one's professional trajectory. However, it is framed more and more as offering the setting for individual employees to enhance their own individual employability. The firm becomes part of a professional field in which employees are responsible for their own professional development by gaining skills, experience and establishing networks. The firm is the context in which one's career unfolds, but the employee is the engineer of her career. Being and remaining employable is an individual strategy. We argue that the employability discourse depoliticizes the relationship between the employee and the employer and shifts the lens towards the individual responsibility for success or failure of the worker herself.

While for some categories of workers this seems like a successful strategy, for others it becomes a race to the bottom. By drawing on empirical material on high-skilled and skilled workers in the city of Cluj, we demonstrate how the employability discourse draws new lines of divisions between employees. While for the high-skilled workers in the IT and HR field shifting between companies and positions and thus constantly gaining new skills builds towards their employability, for the skilled workers in the industry experience and skills 
make them redundant and practically less employable. By questioning the very assumption that employability is an individual strategy and a one-to-one relationship between employer and employee, we aim to unpack the classless imaginary of the employability discourse and assess the political consequences for the workers.

\section{The employability discourse and its effects}

Despite diminishing levels of European aggregate demand for jobs after 2008 (Gros 2019; Picketty et al. 2018) and "transitional unemployment" before 2008 (Bell and Mickiewicz 2013) many Central and East European (CEE) cities were able to reposition themselves in the global urban hierarchy (Raźniak, Dorocki, and Winiarczyk-Raźniak 2018; Derudder and Taylor 2016). The expansion of globalization after the 2008 Financial Crisis was enabled by the relocation of corporations' secondary processes to new areas specialized in operations (Oshri et al. 2015; Peck 2018). Most of the outsourcing processes are Business Process Outsourcing and Information Technology Outsourcing (Oshri et al. 2015). In Europe, most of the outsourcing is in CEE (Peck 2018). The recent round of outsourcing is driven by labour arbitrage and involves skilled and highly qualified labour force (Peck 2018). Along with the repetitive IT activities transferred to the region, there is also a rise in R\&D activities. In CEE the "portfolio worker" was welcome as a positive development as the social structure of the city accommodates an expansion of the professional positions (Eurobarometer 2016) at the expense of the blue collar workers relocated in the suburbs and surrounding towns (Nemeškal, Ouředníček, and Pospíšilová 2020; Slaev et al. 2018) However, for those in the new job the firm became unreliable in providing a secure position (Bell and Mickiewicz 2013). Instead, the firm came to offer the possibility of enhancing one's employability (Chertkovskaya et al. 2013). Employability promises the freedom to choose between successive positions and transform them into learning experience part of a career (deBruin and Dupuis 2008; Iellatchitch, Mayrhofer, and Meyer 2003).

The employability discourse and the idea of building a career-trajectory across firms is rooted in the expansion of the service sector and the changing social stratification of urban CEE (Słomczyński et al. 2016). These transformations take place not only in big cities (Sýkora and Bouzarovski, 2012), but also in second-tier cities in the region (Evans, 2015). Such a city is Cluj, a second rank city in Romania with a population of 325000 . The city rescaled itself becoming an important player, successfully repositioning in the financial sector, production services and intensive-knowledge services (Gál, 2014; Petrovici and 
Simionca, 2011). The new hero in the public discourse became the creative, selfdeveloping, self-improving, cheap and disciplined subject (Mihály, 2015; Petrovici, 2012; Simionca, 2016; Zincă, 2011). Between 2008 and 2018 the jobs in the service sector grew with $30 \%$, while the numbers of industrial workers decreased with almost $10 \%$ in the city, but remained the same in the metropolitan area.

In CEE criticism old Fordist loyalties and the complex bureaucracies of the factories is played out as a critique of "communism" (Ban, 2014; Buden, 2010; Simionca, 2012). The employability agenda has at its centre a particular work ethic sustained by the self-government techniques of the flexible, skilled, and enterprising subject (Chertkovskaya et al., 2013). This work ethic promises a very different subject from the communist or Fordist subject. These discursive formations are not exceptional for Eastern Europe. Much of the current work arrangements in core capitalist countries can be linked exactly to the ability to capture employees' criticism and discontent with the arrangements of the bureaucratic organization (Burawoy, 1985; Sennett, 1998; Bloom, 2013). The strive towards independences and freedom from the heavy bureaucratic machine has been adapted to produce an entrepreneuring self in the confines of the capitalist firm (Boltanski and Chiapello, 2005).

Critical scholars have pointed that employability prompts a new dependence to the manager's figure (Cremin, 2010). Arguably employability produces an idealized identification with the manager's desires, found in the hope that the employee's vulnerability in the organization may be overcome by assembling the various managerial needs and job openings into a career (Bloom, 2013). Inside this narrative the burden of organizational flexibility is put on the shoulders of the employee encouraged to improve herself and to find new opportunities, once the organizational milieu is no longer acceptable (Alvesson and Sveningsson, 2008). Organizational claim making is hindered by continuous individualization and depolitization of the work relations (Garsten and Jacobsson, 2013; Sharone, 2007; Garsten and Jacobsson, 2004). The employee is decoupled from any internal control, except the informal relations developed with supervisors and colleagues, and reoriented towards the career field (Gunz and Peiperl 2007; Iellatchitch et al. 2003).

Such critical appraises open new ways to unpack the complex relation in which the employees are made part of and asked to contribute to a firm. Employability does not suspend the conflict-ridden character of the social divisions of work that are in place both in the industrial and post-industrial arrangements. But much of the struggles between labour and capital are deflected as tensions between the working classes, understood as fluid groups formed in the division of labour (Kasmir and Carbonella, 2014). The tension between highskilled workers and unskilled workers on the shop floor are well documented 
(Pittaway, 2007; Burawoy, 1985; Petrovici, 2011), as are the alliances that are formed between the different workers factions against the employer (Ost, 2002; Kalb, 1997). Employability increasingly transfers the burden of being employed on the working subject, on the supply side, rather than on a complex interaction between the labour market, the economic conditions, the social reproduction etc. (McQuaide and Lindsay 2005). Consequently, unemployment, precarious working conditions, working routine, and job estrangement are explained as an individual malaise, the result of a not good enough self-entrepreneurship. The subjects are encouraged to evaluate and position themselves in relation to other workers, but not to challenge the working condition and the employer. Structural transformations in the labour market are transformed in individual employability problems (Peck and Theodore, 2000).

In what follows we explore how the employability discourse reflects class divisions between the two categories of workers. We argue that for the high-skilled the employability discourse leads to a successful career trajectory, while for the skilled workers becoming more skilled is a road towards becoming less employable. By drawing on our empirical material on high-skilled and on skilled workers in the city of Cluj, we demonstrate how the employability discourse draws new lines of divisions between employees. For the high-skilled workers in the IT and HR field shifting between companies and positions allows them to gain new skills, and subsequently raise their employability. For the skilled workers in the industrial sector growing experience and skills on the contrary, makes them less desirable as workers and places them in a precarious position. By questioning the very assumption that employability is an individual strategy and a one-to-one relationship between employer and employee, we aim to unpack the classless imaginary of the employability discourse and assess the political consequences for the workers.

We develop this argument in three parts. We first describe our methodological approach, the professional fields and the main concepts. Second, we focus on how our respondents describe and make sense of the concepts of skill and expertise. We look at the narratives of personal development, self-improvement, and self-education as blocks in the employability narrative. We analyse the different paths and strategies used by the two categories of workers and how they evaluate their success in becoming employable. Finally, we show how employability as a discourse is an individualizing strategy that focuses on the personal qualities of the worker taking away the responsibility from the firm. We show how in this context employability is instrumental in the process of depolitization of labour relations between the employee and the firm and in the creation of a classless imaginary. 


\section{Methodology and main concepts}

The empirical material was gathered through qualitative interviews with two categories of actors: high-skilled workers in the IT and HR sectors, and skilled workers in industrial settings. The research took part in two stages: the first in late 2013 - early 2014 when we conducted 46 semi-structured interviews, and the second in 2019 when we conducted additional 23 interviews and analysed the most recent statistical data on the development of Cluj and its metropolitan area.

The empirical material was conducted through semi-structured interviews that we conducted with the help of six research assistants. We used our personal connections and the snowball effect. Over the two research stages out of the total of 69 interviews 43 are with high-skilled workers. The median age of highly skilled workers is 28 , the gender ratio is $71 \%$ men to $29 \%$ women. The average age of schooling is 13 (i.e. high-school and two years of BA level university education). The types of positions they occupied are junior developer, senior developer, tester, team leader, project manager, business developer, IT sales, HR specialist, HR manager.

We have conducted 25 interviews with skilled workers. The positions they held were: warehouse supervisor, storekeeper, technical shift supervisor, electrician, plumber, textile machine operator. Their average years of schooling is 12 (i.e. high school education). Their average age is 48. Clearly there is an age difference in the samples. This is not by accident. The IT and HR sectors are fast developing, dynamic, constantly growing fields in Cluj attracting a big part of the recent university graduates directly into the labour market. At the same time, the small-scale manufacturing companies have mainly low-skilled workers in their labour force with a small number of skilled workers who are generally older. Our sample reflects this reality of age disparity in the different sectors. And it has further implications for the way those employees conceptualize and experience the narrative of employability.

Statistical data was used to assess the transformations in the IT sector in Cluj and the metropolitan area in terms of re-industrialization processes over the last 10 years. This allowed us to also position Cluj as a specific type of town. The professional fields are chosen in light of these developments of Cluj and its metropolitan area over the last decade. Cluj is one of the fast-growing IT hubs in Romania with a constant growing number of companies and employees. The Information technology sector (IT) and Human resources (HR) are two loosely constructed professional fields. The IT sector is the largest in the city with more 
than 7500 employees or $7 \%$ of the total workforce 4 .It is strongly driven by the global fluxes of capital, most of the projects are outsourced by multinational companies. Public university courses at all levels (BA, MA, PHD) offer specialization in IT and hardware development. Private companies also offer more specialized courses. The IT boom and the reindustrialization processes contributed to a growing HR professional field. ${ }^{5}$ Public universities in Cluj now offer HR specialization tracks at BA and MA level in addition to a multitude of trainings, courses, and internships, offered by private companies. While in the early employees in IT and $\mathrm{H}$, did not have a particular educational profile or even a tertiary degree, now specialized higher education profiles are growing in importance alongside specialized internships, trainings and workshops (Simionca and Al Ariss, 2011).

Most of the new industrial jobs are in the metropolitan area, while the IT jobs are in the city centre. BOSCH opened a factory for 3,000 workers in a nearby village and an R\&D Center for 700 people in the city. Similarly, Tenaris has a factory in a nearby smaller town, while their regional and global shared service center is in Cluj. In 2018 in Cluj and its metropolitan area there were 43675 jobs in manufacturing, representing $18 \%$ of the total number of employees in the area.

The two categories we delineate here - high-skilled and skilled workers are analytical constructs that describe different types of positions and experiences in the grid of professions and the specifics of the labour market in Eastern Europe. We acknowledge that 'skill' is a constructed and flexible concept and the categorization of workers along the spectrum of skill is a dynamic process. For the sake of clarity, we have chosen to call high-skilled workers those of our interviewees who work in the IT sector and in HR, most of them with higher education degrees. By skilled workers we mean different categories of technicians and machine operators engaged in the manufacturing sector. The skilled workers are people with tertiary education, working in small manufacturing companies as operators of machines. The differences between the two categories of workers are not only based on how their skills are categorized, but also on the sectors, the dynamic of labour relations and the type of production in

4 At the 2011 census there were 6,441 employees in the IT field at all organizational levels, from managers to data operators, representing $13.25 \%$ from the total service employees in Cluj city. In 2018 there were 22.102 employees working in IT, that is $20 \%$ of the total employees in the service sector and $11 \%$ of the total number of employees in the city of Cluj.

5 At the 2011 census there were 1282 employees in the HR field at all organizational levels, representing 2.64\% from the total number service employees in Cluj city. The number of employees in HR did not grew per se in the last years, since the profession changed substantively, became part of the growing field of the Business Support Services that amassed by 2018 11,177 employees. 
which they are engaged. In what follows we aim to show how these constructed differences are rooted in the different sectors and in the value that is attached to these sectors and types of jobs available.

\section{Skills, expertise, and personal development: becoming more employable or falling into redundancy}

Historically, an unintended effect of planned economies was that the whole system became dependent on the collaboration and flexibility of direct producers (Pittaway, 2007; Petrovici, 2011). As a reaction to the dependence on the willingness of workers to informally mobilize for fast and concentrated production stints, the socialist management tried to hold a grip on the production processes by inventing continuous new rules and hierarchies (Pasti, 1997). The decision-making process was very long, precisely because there was a whole layer of highly skilled workers simultaneously in charge and responsibilities were unclear. In the first post-socialist decade much of the criticism voiced by the socialist highly skilled workers went into producing a counter-organizational discourse against the socialist factory's impossibility of real control, lack of bureaucratic creativity, and rigidity.

In Cluj, most of the contemporary large firms emerge in the second part of the 1990s and were run by these young high-skilled workers (Petrovici and Simionca, 2011). The language of flexibility and creativity became a tool to refashion the new organizational milieu (Zincă, 2011; Simionca, 2012). Most of the business literature and business contacts encouraged reframing this genuine criticism into neoliberal parlance. Since the new local business scene was just emerging, the socialist highly skilled workers had the chance to put critical concepts to test, while reinventing themselves and the business milieu. By the early 2000s the trope of creativity, venture and self-development became the lens through which this social group saw the economy and the world. However, for the new generation of high-skilled workers entering the labour market, the discourse was already of a naturalized flexible subject (Zincă, 2011). And by extension, an anti-communist discourse framed their criticism of the planned, large-scale industrial Taylorism (Simionca, 2012). "Capitalism" is often read, with the active help of public intellectuals, as a political-ethical project that aims not only to politically design markets, but also to enact a moral transformation: to get rid of the old communist habits and practices.

In the next two subsections we show how the employability narrative and the strategies to secure it is experienced and conceptualized by the two categories of workers. Developing new skills and expertise in a certain field is 
interpreted differently by the two categories. For the high-skilled, the new skills are part of a chain that forms their professional development. Acquiring skills in different spheres, on different positions, is part of a quest towards a successful career. New positions bring new skills - technical, administrative, managerial, or interpersonal (soft skills). Thus, changing positions is part of building a career. For the skilled workers, on the other hand, developing better skills as such often work in the opposite direction making them more expensive for the employer, with higher requirements. Experience, paradoxically, is a hindrance and in some cases leads to redundancy and being exchanged with a less experienced worker. Careers among the skilled workers are rather flat and the main aim is to keep one's job, rather than develop or grow in the hierarchy. In what follows we develop these two lines of interpreting the concepts of skill, professional development, and career trajectories in the context of the structural differences of the two sectors.

\section{The high-skilled: professional fields and personal development in the quest to employability}

The high-skilled workers' narratives echo the discourse where creativity, self-development and self-improvement are at the centre of being a good employee and an accomplished modern subject. The two major themes in our interviews are the quest for personal development and the process of discovering and constituting a professional field. The quest constitutes of acquiring new skills, improving the ones that one already has, but also moving between different positions. This results in a professional trajectory that one might call a successful career. The main responsibility is of the individual and her efforts to construct a professional self through her personal efforts and choices.

The other main theme is establishing expertise in a professional field. The expertise is built on improving and developing skills and on the variety of positions held. The professional field is key for unfolding one's expertise. It develops in a field that is often considered as constructed and dynamic. Some professional fields already exist like coding, business intelligence or machine learning expert, but have been further developed to fit the needs of the concrete market niche by the employees themselves. Contributing towards establishing a field or a subfield is considered a sign of being a good professional. Changing positions within the same company or expanding the tasks within a position contributes to establishing new frontiers of a professional field or laying the ground for field partitioning (Faulconbridge and Muzio, 2019). In this sense, there is a dynamic relation between the individual career of an employee and 
the professional field. Employability for the high-skilled means both building a good resume by improving and multiplying one's skills, and positioning oneself as an expert in a particular professional field. Those two are part of the quest for improvement and development that ultimately make one more employable.

There is a complex dynamic between the individual efforts that each employee is supposed to make into their own professional development and the role of the firm. The firm plays a major role in this quest, as an enabling milieu for professional development and for identifying and constructing the professional field. However, the firm can also pose barriers on the personal development, experience acquisition and the sense of dignity that is needed to an enabling environment conducive to self-improvement. The firms are evaluated and classified according to their capacity to facilitate or hinder one's development.

Practical knowledge and skills are assembled into new positions that could grow into professional fields or subfields. Fields are described by employees as flexible and with blurred boundaries. The head of the HR in an IT company with 700 employees recollects that initially she was working in business development. Meanwhile, she also started working with employees directing them into career paths inside the company. She combined her knowledge of the business side of the company with her HR background to develop a position of career manager (or lead in other companies) who creates and directs career tracks, invents incentives, and sets up teams for specific jobs. The HR development unit became real when professionals start practicing these activities and naming them with a particular label. This field is confirmed through similar positions in different firms. What is more, the field is actively produced by the efforts of the individual workers to discover a meaningful and inspiring sphere of activities by moving between companies. The perfect professional field to be active in is described by our respondents as an area of expertise wide enough to be recognized as legitimate by a multitude of firms, yet specific enough to be still rare on the labour market. Firms alone cannot provide the needed expertise for establishing and legitimizing a professional field. As one respondent working in HR says:

HR is a new domain here in Romania and the company where I worked was a bit clueless on what tasks to give to the HR team, except hiring. But there are meetings with other people working in HR, recently there are more and more people who actually graduated from this degree, there are job-fairs, and conferences. So, then you mix with other colleagues, learn new things. Our team is now doing many activities, because of this constant exchange of experience. (I., 32, HR) 
In the field of HR the parallel knowledge networks that include universities, academic research teams, training organizations that provide certification are particularly important for establishing the professional field and its subfields in Cluj. In addition, there are state institutions (Work Inspectorate, Workforce County Agency) that offer qualifications, standards and supervise the labour laws application. The corporate responsibility programs and volunteering projects also offer HR practitioner spaces to exercise new ways of holding together a team through motivational strategies. All these are expanding and deepening the expertise of a (sub)field and sustain its reality outside of the concrete firm.

The term "experience" codes the ability to navigate expertise in the networks of firms. Experience is the basic measuring unit that our respondents used to describe advancing in their careers. Future jobs, better pay, growing in the hierarchy depend on having experience. Experience, ideally, does not limit the worker to one particular firm. Experience in a field is what makes one employable in different firms and at different positions. Our respondents explained that building up experience is primarily an individual strategy. It is the desire, efforts and determination of the worker to keep developing professionally by acquiring new skills.

Even when the firm is involved in this narrative of building experience, our respondents addressed it in a non-organizational way. The IT companies often have a position of a 'lead' named differently in the different companies, who mentors the employees through their trajectory, discussing with them the type of projects that they are willing to take. The career of a developer, for example, is constructed based on the interests and desires, but also the personal skills of an employee that are discussed together with the 'lead'. While the company provides this position, it is concentrated on the specific ambitions of each employee.

Second, there is the personal responsibility for acquiring experience, in spite of any organizational drawbacks. As an IT employee jokingly puts it, when talking of scarcity of training programs, the firms still offers someone the possibility to become a "google engineer". That is, when one is assigned a new task that can only be solved through individual research in search engines. The disadvantage of not providing institutional training is reinterpreted as an advantage for the employee who becomes indispensable by self-training. Similarly, in the HR field, the individual efforts that go beyond what is required by the position, are considered investing simultaneously in one own's professional development and at the same time in the establishing of the firm (see more on knowledge appropriation and resistance in Kamoche 2011). One of our respondents, a mid-level HR Specialist with six years of experience in recruiting 
explained how she invested in her own professional development, beyond what was required by her firm, and in that way became a more valuable asset for the firm:

I did human resources courses at individual psychology offices, there I did the recruiting, job analysis, selection, evaluation, training, coaching and so on. I have also been involved in the research at the Faculty [of Psychology] and I have been involved in EU funded projects, especially on corporate social responsibility... I got involved in all kinds of trainings, courses ... I went to a lot of workshops. Now, I want to attend as many human resource conferences as I can, since it is very important to expand your social network because you work with both clients and state agencies You work a lot with the labour code, at least from my position, and it is very important to know, to ask, to receive answers. (F, 25, HR Specialist, IT firm)

To sum up, employability as a discourse among the high-skilled is oriented towards personal and professional development. It includes becoming an expert, by building up experience through acquiring new and various skills. An employee becomes more employable if the experience and expertise are directed towards constructing a professional field in which one is an indispensable expert able to navigate between various firms. This is an individual enterprise, even though the firm is expected to provide an enabling environment.

\section{Experience and skills as barriers to employability: the skilled workers}

For those with tertiary education (above high-school) there is evidence in the literature that can certify the global character of the personal development narrative (Valenzuela, 2013; Fejes, 2010). But this narrative is also increasingly documented among those with secondary education. A new wave of studies have shown that various programs of enhancing the employability of long term unemployed (Garsten and Jacobsson, 2013), socially marginalized (Simionca, 2013), or people with disabilities (Elraz, 2013), measure success in terms of the capacity of the trainee to adopt the discourse of self-improvement. A major part of the structural funds available at EU level are targeting explicitly the enhancement of human capital through instruments of raising the quality of human resources across national states. Through these programs (e.g. European Social Fund, Operational Programme for Human Resources Development, European Globalisation Adjustment Fund) a new generation of projects for training the labour force have emerged also in Romania, devised explicitly to promote self-enterprising selves, self-development and self-betterment of the 
employees (Pavel, 2011; Simionca, 2013). The firms themselves are accessing directly these programs and are providing for their employees a variety of media and trainings that put forward narratives of the enterprising worker (Zincă, 2011).

For our respondents, the theme of employability is highly ambivalent. On one hand, the themes of the importance of formal-education, self-education and personal development were also key issues raised by the skilled workers engaged in manual jobs as technicians and operators of machines. As was the case with the high-skilled workers, the manual workers are also invited to use these narratives through the practices of CV writing, self-presentation during the job interviews, or for organizational claims making. However, in most of the cases, these points came up in an opposition to the reality of their working lives. Our respondents described this employability narrative as empty efforts on a policy level (the Ministry of Employment, the Labour bureaus etc.), rather than an actual successful strategy for remaining employed or finding a new job. Their practice showed that skill, experience and expertise do not necessarily make the skilled workers more employable. On the contrary, many of our respondents reported that they had fewer chances of keeping a job or getting a new one if they were in the category of experienced middle-age workers.

There are four ways in which their claims based on qualification, skills and experience have been blocked by the employer. First, skilled workers with experience and a wider set of skills were often replaced by younger inexperienced workers, looking for an entry position. In this sense, skill is not valued and does not bring job security or make a skilled worker easily employable at a different company. On the contrary, the firms are actively engaged in undermining such a fantasy through arbitrarily dismissals, reducing the numbers of the high-earners among the skilled workers, and understaffing while constantly threatening with the available reserve army of workers.

The second employer's strategy is preferring employees looking for extra income: pensioners or commuters with a rural household and subsistence farming. These workers are usually cheaper than the experienced skilled workers. We illustrate this with the excerpt from the interview with a skilled worker, currently holding a supervising position in a high-tech logistic company in Cluj. He explained how he was fired from his previous manufacturing job and replaced by younger unskilled workers and pensioners.

You send your CV and they see that you are in your 40s, and they employ someone in their 20s. "This one is an old worker, for sure he'll have pretensions for higher salary. A junior does not talk back". Instead of taking a good craftsman, who is retiring in 4-5 years, employers prefer younger and cheaper employees, who know nothing. They employ them and 
qualify them for 2-3 years, but pay them cheap. The boss where I worked had very good craftsmen who knew all the products. He closed the factory [in Cluj], dismissed everyone and opened a factory in Bucharest. He hired pensioners who had nothing to do with carpentry. And he took also some youngsters. He preferred to qualify them, even though his products already had a standard. (B, 40, warehouseman).

A third strategy to limit the number of skilled workers is through technological improvements. The skilled manual operator is made redundant by technological upgrades and sometimes replaced by unskilled operators. Therefore, there is always the spectre of being unemployed, regardless of the skills, experience and expertise that one might have. In the case of the manual workers, qualification does not add up in a transferable skill that can be relocated to another job, as in the case of the highly skilled workers. The skills one learns in operating a particular machine, in a specific industry, is most of the times limited to that specific company.

Throughout the twentieth century the mechanical automation economically devaluated the skillsets and practical knowledge of the trained workers, parallel with the valuation of the new skills of white collar workers and engineers (Braverman, 1974; Burawoy, 1985; Vallor, 2014). The narratives of our respondents can be framed within this greater trend. Yet, what is different is the way work is embedded in the discourse of self-improvement. The promise of employability is packed for the skilled workers as a promise for a career between firms for the few selected: for the strongly disciplined, accepting lower wages, and skilled enough to tailor customized products. A skilled worker who works in a paper mill explained how the technological upgrading of the company lead to several waves of dismissals. He kept his job by switching to providing handmade customized services.

And they brought new tools. What we were doing manually now is done with automatic machines... the machine took most of our work. We [the employees] do now only personalized envelopes, for small orders. If there are orders, there is work; if there is no demand, there is no work. Slowly they started laying off people. There were three waves, or so. People were asking "why me, why not the other? Why exactly me?" Yeah... so there is this norm, it is specified in the contract that if you do not accomplish the norm.... You are out if you are on red.... "Who should I kick out?" Well, they kicked out those who were on red repeatedly. You can't lay off the hard-working ones. (B, 50, paper mill worker, secondary education) 
In this quote we also see the fourth strategy of employers to undermine qualifications based claims - emphasis on transforming self-discipline into a skill. A move that is also deeply gendered. Most of the women among the skilled workers we interviewed report that they can find work easier than men. That is not surprising, given that some key routine manual labour markets are feminized (manufacturing in multinationals, hospitality, restaurants and coffee shops, retailing, the health system, education). An illustration of this point, is an interview with a family where both spouses, in their forties, where employed in the same firm. He was made redundant, while she kept her job. During the interview she talked with pride about her ease to work with anybody, her capacity to be part of any collective, and the fact that she had not lost any job until then. A major source of dignity comes from her diligence and willingness to work under any condition. She noticed that while for her is very easy to find new jobs, for her husband it is a toil finding work. She attributed her ability in keeping jobs exactly to her industriousness. Her husband was unemployed. To explain his situation, he mobilized the argument of the undesirability of more experienced male workers as 'trouble makers', who always negotiate and question labour conditions. Women or inexperienced younger men are preferred, because they work hard and ask no questions, he said. This type of reading of the labour market by the subjects themselves can be easily seen as a way to problematize, through the lens of gender roles, that discipline is preferred to skills in the manual sectors. Industriousness and willingness to accept any conditions to keep a job are actually recurrent themes that appear in the interviews with skilled workers, regardless of their gender.

Therefore, the ambivalence of the skilled workers with regard to the theme of professionalization and acquiring abilities is linked to the particular way in which they are embedded in the firms, offering such jobs. Employability in this case means becoming more willing to accept contexts of discipline, overtime, small wages, and no transferable skillsets. As other authors have observed, contemporary deskilling is not anymore a pressure on the work content through routinization by means of automation, in the classical sense of (Braverman, 1974). It is rather linked to the fact that jobs lost through the introduction of information and communication technologies are putting pressure on the not yet dismissed employees to comply (Baccini and Cioni, 2010). Second, acquiring skills are decreasingly imagined by the workers themselves as resource for long time employment in a firm or a resource that enhances employability between firms (Vallor, 2014), given the potential threat of relocating productionrelated occupations. The way this is narrativized by the Cluj skilled interviewees is through the theme of the "willing employee". Industriousness and selfdiscipline become skills. 


\section{Employability and the depolitization of the employee-firm rela- tionship}

While firms are evaluated and held accountable for providing an adequate environment for personal development, our respondents proposed a more complex narrative about the barriers to personal development. The highskilled employees in the IT sector emphasized the organizational structure: the hierarchical character of decision making, the lack of information sharing of managerial strategies, the incomprehensive character of introducing rules and regulations, little control over the terms of the contracts signed with the clients, little control over the personal retention policies, the burden to train the new colleagues without any reduction of the current tasks, over-burdening with responsibilities if competences are shown. Interestingly, all these points are rarely labelled as critique towards the firm itself. In most of the interviews, these critiques surfaced while discussing the personal character of the colleagues and supervisors or about the organizational skills of managers and owners.

The skilled workers have a different take on the structural problems. In their narratives, it is not about the particular company, but about the systemic problem of socialism versus capitalism. Communism is described as a system of equality and fairness, where all workers benefitted from the industrialization and development. "There is no more that middle layer, now there are either poor or wealthy. Before [in communist times] there were all...in the middle. There is no middle class anymore" (M, 40, skilled worker, secondary education). This type of narrative is hardly specific to Cluj. The workers in core capitalist countries are also nostalgic for the security offered by the Fordist arrangements. But what is specific here is that the old factory security is equated with socialism, and the new flexible contracts with their precariousness are equated with capitalism. The interviewees superimpose on the socialist factory the fond memories of solidarity and steady jobs, and consider the contemporary capitalist reality as harsh uncaring environment. What we see here is a clear class and generational divide between the high-skilled and the skilled workers that offer different interpretations of their working lives.

Yet, for both categories the firm itself is not the main locus of responsibility. The individual worker carries the main responsibility for work success or failure. The employability discourse, paired with a focus on the personality of the manager, shift the lens from the firm and the structural conditions to the personal character of the individual and their own abilities to produce a successful working subject. In this sense, job security claims are transformed into issues pertaining to the subject's worth. They depoliticize the employee's relation with the firm by politicizing the relation of the subject with herself and with the other workers, occupying various positions in the social division of labour. 
For the high-skilled the inability to get or keep a job is above all a personal failure. Three types of anti-heroes emerged in the interviews: the lazy, the unwise skill entrepreneur, and the communist. The first anti-hero, the lazy, has difficulties finding and keeping a job simply because of unwillingness to work. It is the person who did not transformed her pleasures of doing something into a job. "I have faculty colleagues who are still not working. Some are too lazy. There are enough places with shortage for staff. If they wanted to work, they would have found a job until now." (M, 25, IT, tertiary education)." Not working is a personal failure of not making enough efforts.

The second anti-hero did not invest wise enough to acquire the right skillsets. "Take Delia's example. She did not find a job, because she did not use her connections with friends and former colleagues, and also because her background is only in logistics" (M, 30, Sell support engineer, tertiary education). Delia had a lot of experience in managing the logistic of a firm. But this limited her field of expertise to only a few potential employers. Then her only chance was to mobilize her networks. This echoes the trope of diversifying one's skills to become an expert in a wider professional field, rather than limiting oneself to one position. Failure to do so is simply an individual predicament outside of the realm of labour relations with the organization.

The third anti-hero is the "communist". The communist is the unwilling worker to learn and to adapt, is the beholder of "old communist mentalities" (see also Petrovici, 2010; Simionca, 2012). No one is exempted from this type of disease, of not being flexible enough. The managers themselves, the supposedly new capitalist figure, cannot be really exempted of this suspicion, even those working in the multinationals: "I can say that also in the multinationals is the same deal as in the small firms. Yes... the managers have the same style of doing stuff: the communist way" (M, 30, IT, tertiary education). Those who do not conform to the requirement of employability are consistently reproached for doing things 'the old way:

I have not lived in the communist era, but all my teachers had lived in the communist period, our parents lived in the communist era, all those in charge now, they lived in the communist period. During the transition from communism to capitalism, many people failed. What I mean is that in capitalism you have to change quickly your whole mentality. You have to change often and very quickly your job, your location very quickly. In communism your job was guaranteed, for life, so you did not have to develop. (Male, 26, IT, secondary education)

In this sense, the anti-communist discourse is intimately linked with the employability narrative. The communist worker becomes the epitome of the employee in search for the stable contract, while the capitalist worker stands 
for the flexible subject. For the skilled workers, while the system is often blamed for their current insecure and unfavourable position, the firm remains out of their radar. It is then either the individual character of the worker or the personality and skills of the manager. The lazy is the main anti-hero in this category. The major filter through which a person's dignity is evaluated is that of his or her industriousness. If someone loses their job, often the explanation is that she was not working hard enough. As we showed in the previous section - industriousness and diligence are considered highly important qualities for the skilled workers. Much more so than experience and skill. The other locus where the skilled workers attribute their work misfortunes is the manager. The employer's quest to devaluate their skills are attributed to the moral flaws of the manager or the owner. Laziness and immoral managers are the two main issues highlighted in our interviews. The firm as such does not enter this relationship of dependency, even in the otherwise insightful analysis of how the employability discourse does not work for the skilled workers.

In conclusion, while the employability narrative depoliticizes the relation between the employer and employee, it politicizes the relationship between employees and the labour market. Claims toward job security, a stable position and sharing the burden of flexibility become increasingly hard to articulate at an organizational level. Getting and keeping a job are a task of the individual and can be achieved through willingness to work and self-improvement. While these are discursive invitations, the surprising effect is that these criteria are used for classificatory purposes by the employees themselves, to assess their own worthiness and worthiness of the others. The employability narrative becomes a lens through which the workers assess themselves and the other workers. It becomes a narrative that politicizes the relation between workers. Yet, not by providing solidarity, but by dividing them in on a scale of worthiness. The struggle between the employer and employees are deflected into tension between the various factions of the working class.

\section{REFERENCES}

Alvesson M and Sveningsson S. (2008). Changing Organizational Culture: Cultural Change Work in Progress Routledge.

Ark Bv, O'Mahony M., Timmer MP. (2012). Europe's Productivity Performance in Comparative Perspective: Trends, Causes and Recent Developments. In: Mas M and Stehrer R (eds) Industrial Productivity in Europe: Growth and Crisis. Cheltenham and Northampton: Edward Elgar Publishing, 65-91.

Baccini A and Cioni M. (2010). Is technological change really skill-biased? Evidence from the introduction of ICT on the Italian textile industry (1980-2000). New Technology, Work and Employment 25: 80-93. 
DEPOLITICIZING THE FIRM: REVISITING EMPLOYABILITY AS A STRATEGY AND A NARRATIVE FOR HIGH-SKILLED AND SKILLED WORKERS IN AN EASTERN EUROPEAN CITY

Ban, C. (2016). Ruling ideas: How global neoliberalism goes local. Oxford University Press.

Banczyk M. (2012). Easter European Cities. In: Peter J Taylor PN, Ben Derudder, Michael Hoyler, Jin Huang, Frank Witlox (ed) Global Urban Analysis: A Survey of Cities in Globalization. London: Earthscan, 293-300.

Bell J and Mickiewicz T. (2013). Unemployment in Transition: Restructuring and Labour Markets in Central Europe, Routledge.

Bernstrøm, V. H., Drange, I., and Mamelund, S.-E. (2019). Employability as an alternative to job security. Personnel Review, 48(1), 234-248.

Bloom P. (2013). Fight for Your Alienation: The Fantasy of Employability and the Ironic Struggle for Self-exploitation. ephemera: theory \& politics in organization 13: 785-807.

Boltanski L and Chiapello È. (2005). The New Spirit of Capitalism, Verso.

Braverman H. (1974). Labor and monopoly capital: the degradation of work in the Twentieth Century, Monthly Review Press.

Buden B. (2010). Children of Postcommunism. Radical Philosophy, 159: 18-25.

Burawoy M. (1985). The Politics of Production: Factory Regimes under Capitalism and Socialism, Verso

Chertkovskaya E, Watt P, Tramer S, et al. (2013). Giving Notice to Employability. ephemera: theory \& politics in organization 13: 701-716.

Cremin C. (2010). Never Employable Enough: The (Im) Possibility of Satisfying the Boss's Desire. Organization 17: 131-149.

d'OIvidio M and Ranci C. (2014). Social Cohesion and Global Competitiveness: Clustering Cities. In: Ranci C, Brandsen T and Sabatinelli S (eds) Social Vulnerability in European Cities: The Role of Local Welfare in Times of Crisis. k: Palgrave Macmillan, 31-65.

deBruin, A., and Dupuis, A. (2008). Making Employability 'Work'. Journal of Interdisciplinary Economics, 19(4), 399-419.

Derudder, B., \& Taylor, P. (2016). Change in the world city network, 2000-2012. The Professional Geographer, 68(4), 624-637.

Elraz H. (2013). The 'Sellable Semblance': Employability in the Context of Mental-illness. ephemera: theory \& politics in organization 13: 809-824.

Eurobarometer. (2016). Quality of Life in European Cities 2015. Luxembourg: Publications Office of the European Union.

Evans, R. (2015). Harnessing the economic potential of 'second-tier' European cities: Lessons from four different state/urban systems. Environment and Planning C: Government and Policy, 33(1), 163-183.

Faulconbridge, J., \& Muzio, D. (2019). Field partitioning: The emergence, development and consolidation of subfields. Organization Studies, first published July 2019

Fejes A. (2010). Discourses on Employability: Constituting the Responsible Citizen. Studies in Continuing Education 32: 89-102.

Gál Z. (2014). Relocation of Business Services into Central and Eastern Europe: Evidence From Trade and Location Statistics. Romanian Review of Regional Studies 10: 67-78. 
Garsten C and Jacobsson K. (2004). Learning to be Employable: New Agendas on Work, Responsibility, and Learning in a Globalizing World. Palgrave Macmillan.

Garsten C and Jacobsson K. (2013). Sorting People In and Out: The Plasticity of the Categories of Employability, Work Capacity and Disability as Technologies of Government. Ephemera: Theory and Politics in Organization 13: 825-850.

Gros, D. (2019). "Improvement in European Labor Force Participation." IZA World of Labor 449.

Gunz H and Peiperl M. (2007). Taxonomy of Career Studies. In: Gunz H and Peiperl M (eds) Handbook of career studies. Thousand Oaks and London: Sage, 29-54.

Gunz, H., Mayrhofer, W., and Tolbert, P. (2011). Career as a Social and Political Phenomenon in the Globalized Economy. Organization Studies, 32(12), 1613-1620.

Iellatchitch, A., Mayrhofer, W. and Meyer, M. (2003). Career Fields: A Small Step Towards a Grand Career Theory? International Journal of Human Resource Management 14: 728-750.

Janicka K and Słomczyński, KM. (2008). Polarized Social-Class Structure: On the Matthew Effect and Increasing Inequality. Polish sociological review 164: 341-357.

Kalb D. (1997). Expanding Class: Power and Everyday Politics in Industrial Communities, Duke University Press.

Kamoche, K., Pang, M., and Wong, A. L. (2011). Career development and knowledge appropriation: A genealogical critique. Organization Studies, 32(12), 1665-1679.

McQuaid, R. W. and Lindsay, C. (2005). The Concept of Employability. Urban Studies, 42(2), 197-219.

Mihály, Z. (2015). The Making of Cheap Labour Power: Nokia's Case in Cluj. Studia Universitatis Babes-Bolyai Sociologia, 6(1), 63-82.

Nemeškal, J., Ouředníček, M., and Pospíšilová, L. (2020). Temporality of urban space: Daily rhythms of a typical week day in the Prague metropolitan area. Journal of Maps, 16(1), 30-39.

Oshri, I., Kotlarsky, J., \& Willcocks, L. P. (2015). The Handbook of Global Outsourcing and Offshoring 3rd Edition. Springer.

Ost D. (2002). The Weakness of Strong Social Movements: Models of Unionism in the East European Context. European Journal of Industrial Relations 8: 33-51.

Pasti V. (1997). The Challenges of Transition: Romania in Transition, Boulder: East European Monographs.

Pavel R. (2011). Social Entrepreneurship and Vulnerable groups. Journal of Community Positive Practices 59.

Peck, J. (2017). Offshore: Exploring the worlds of global outsourcing. Oxford University Press.

Petrovici A. (2010). Neoliberal Managerial Styles in a Postsocialist Environment. Studia Universitatis Babes-Bolyai-Sociologia: 61-80.

Petrovici N. (2011). Articulating the Right to the City: Working Class Neo-Nationalism in Postsocialist Cluj, Romania. In: Kalb D and Halmai G (eds) Headlines of $\mathrm{Na}$ tionalism, Subtexts of Class. Berghahn Books, 57-77.

----- (2012). Workers and the city: Rethinking the geographies of power in post-socialist urbanisation. Urban Studies, 49(11), 2377-2397. 
DEPOLITICIZING THE FIRM: REVISITING EMPLOYABILITY AS A STRATEGY AND A NARRATIVE FOR HIGH-SKILLED AND SKILLED WORKERS IN AN EASTERN EUROPEAN CITY

Petrovici N and Simionca A. (2011). Productive Informality and Economic Ties in Emerging Economies: The Case of Cluj Business Networks. In: Bhambry T and Griffin C (eds) Transformation and Transition in Central and Eastern Europe \& Russia. University College London, 134-144.

Pittaway M. (2007). The Revolution and Industrial Workers. Hungarian Studies Review XXXIV: 115-154.

Raźniak, P., Dorocki, S., and Winiarczyk-Raźniak, A. (2018). Eastern European cities as command and control centres in a time of economic crisis. Acta Geographica Slovenica, 58(2), 101-110.

Sennett R. (1998) The Corrosion of Character: The Personal Consequences of Work in the New Capitalism, New York: WW Norton \& Company.

Sharone 0. (2007). Constructing Unemployed Job Seekers as Professional Workers: The Depoliticizing Work-Game of Job Searching. Qualitative Sociology 30: 403-416.

Simionca A. (2012). Neoliberal Managerialism, Anti-Communist Dogma and the Critical Employee in Contemporary Romania. Studia Sociologie 57: 125-149.

-----. (2013). Development, Underdevelopment and Impoverished Roma Communities. A Case Study of High-Level Visions and Agendas of Economic Progress In Urban Romania. Studia Universitatis Babes-Bolyai-Sociologia 58: 55-75.

(2014). The Precariousness of the Employable. Highly Skilled Professionals in Contemporary Romania. ERSTE Foundation Fellowship for Social Research Labour Market and Employment in Central and Eastern Europe

-----. 2016. "Personal and Spiritual Development in Contemporary Romania: In Search of Ambivalence." Studia Universitatis Babes-Bolyai Sociologia 61 (2): 11-25.

Simionca A and Al Ariss A. (2011). A Multilevel Understanding of the Career Experiences of Middle Managers in Romania. The 7th International Critical Management Conference, 11-13 July. University of Naples FedericoII.

Slaev, A. D., Nedović-Budić, Z., Krunić, N., Petrić, J., \& Daskalova, D. (2018). Suburbanization and sprawl in post-socialist Belgrade and Sofia. European Planning Studies, 26(7), 1389-1412.

Słomczyński, K. M., Tomescu-Dubrow, I. Życzyńska-Ciołek, D and Wysmułek, I. (2016). Dynamics of social structure: Poland's transformative years 1988-2013. IFIS PAN Publishers.

Stanilov K and Sýkora L. (2014). Confronting Suburbanization: Urban Decentralization in Postsocialist Central and Eastern Europe, Wiley-Blackwell.

Sýkora L and Bouzarovski S. (2012). Multiple Transformations Conceptualising the Post-communist Urban Transition. Urban Studies 49: 43-60.

Taylor PJ, Derudder B, Hoyler M, et al. (2012). European Cities in Globalization. In: Taylor PJ, Ni P, Derudder B, et al. (eds) Global urban analysis: A survey of cities in globalization. Routledge.

Tomescu-Dubrow I. (2011). Effects of Future Orientations on Income Attainment and Social Class: An Analysis of Polish Panel Data. Polish sociological review 176:514-532.

Truc G. (2011). Narrative Identity against Biographical Illusion: The Shift in Sociology from Bourdieu to Ricœur. Études Ricoeuriennes/Ricoeur Studies, 2: 150-167. 
Valenzuela F. (2013). On Employability in Higher Education and Its Relation to Quality Assurance: Between Dis-identification and De-throning. ephemera: theory \& politics in organization 13:861-873.

Vallor S. (2014). Moral Deskilling and Upskilling in a New Machine Age: Reflections on the Ambiguous Future of Character. Philosophy \& Technology first online:1-18.

Vincze E. (2013). Urban Landfill, Economic Restructuring and Environmental Racism. Philobiblon: Transylvanian Journal of Multidisciplinary Research in Humanities 18:389-405.

Zincă I. (2011). Grounding Global Capitalism in Cluj-Napoca, Romania. On Teritorialization and the Question of Agency. Studia Sociologie 56:139-156. 